УДК 618.36-02:618.393

DOI 10.11603/24116-4944.2016.2.6855

\author{
๑А. В. Бойчук ${ }^{1}$, I. М. Нікітіна ${ }^{2}$, С. А. Сміян ${ }^{2}$, Б. М. Бегош ${ }^{1}$ \\ ${ }^{1}$ ДВНЗ «Тернопільсъкий державний медичний університет \\ ілені І. Я. Горбачевсъкого МОЗ України» \\ ${ }^{2}$ Сумсъкий державний університет
}

\title{
МОРФОЛОГІЧНІ ОСОБЛИВОСТІ ПЛАЦЕНТИ ПРИ БАГАТОПЛІДНІЙ ВАГІТНОСТІ
}

МОРФОЛОГІЧНІ ОСОБЛИВОСТІ ПЛАЦЕНТИ ПРИ БАГАТОПЛІДНІЙ ВАГІТНОСТІ. Проведено КЛініко-імунологічне дослідження послідів жінок з багатоплідною вагітністю, відзначено наявність морфоорункціональних, імунопатологічних змін різного ступеня вираженості. Доведено, що у жінок з невиношуванням вагітності при багатоплідності ступінь фретоплацентарної недостатності залежить від кровопостачання плаценти і характеру запальних проявів. Вивчено морфологічну картину плацентарних порушень при невиношуванні вагітності. Виявлено, що морфологічними ознаками фретоплацентарної недостатності при неінфекційних факторах невиношування вагітності є: ранні зміни в судинах децидуальної оболонки у вигляді спазму, облітерації просвіту спіральних артерій, зменшення обсягу судинного русла ворсинчастого дерева, зменшення обсягу хоріонального епітелію і периферичного трофобласта, збільшення відкладень материнського і плодового срібриноїду. Проведені дослідження дозволяють сформувати чітку концепцію патогенетично обґрунтованої терапії пренатальних ускладнень, що виникають при багатоплідній вагітності.

МОРФОЛОГИЧЕСКИЕ ОСОБЕННОСТИ ПЛАЦЕНТЫ ПРИ МНОГОПЛОДНОЙ БЕРЕМЕННОСТИ. ПровеДеНО КЛИНИКОиммунологическое исследование последов женщин с многоплодной беременностью, отмечено наличие морфофункциональных, иммунопатологических изменений различной степени выраженности. Доказано, что у женщин с невынашиванием беременности при многоплодии степень фетоплацентарной недостаточности зависит от кровоснабжения плаценты и характера воспалительных проявлений. Изучена морфологическая картина плацентарных нарушений при невынашивании беременности. Выявлено, что морфологическими признаками фетоплацентарной недостаточности при неинфекционных фракторах невынашивания беременности являются: ранние изменения в сосудах децидуальной оболочки в виде спазма, облитерации просвета спиральных артерий, уменьшение объема сосудистого русла ворсинчатого дерева, уменьшение объема хорионального эпителия и периферического трофробласта, увеличение отложений материнского и плодного фрибриноида. Проведенные исследования позволяют сформировать четкую концепцию патогенетически обоснованной терапии пренатальных осложнений, возникающих при многоплодной беременности.

MORPHOLOGICAL FEATURES OF THE PLACENTA IN MULTIPLE PREGNANCIES. Clinical and immunological research of placentas in women with multiple pregnancy was conduted. There was noted the presence of morphological and functional, immunopathologic changes of varying severity. It is proved that in women with miscarriage at the level of multiple pregnancy placental insufficiency depends on the blood supply to the placenta and the nature of the inflammatory manifestations. The morphological pattern of placental disorders in miscarriage was revealed that the morphological features of placental insufficiency in non-infectious factors of miscarriage are early changes in the vessels of the decidua in a spasm, obliteration of the lumen of the spiral arteries, a decrease of vascular villous tree, reducing the amount of chorionic epithelium and peripheral trophoblast, increased maternal and fetal deposits fibrinoid. Thanks to the research it will be possible to form a clear vision that would allow on the basis of public spending immunomorfological features pathogenetically substantiated therapy prenatal complications arising from multiple pregnancies.

Ключові слова: багатоплідна вагітність, монохоріальна, дихоріальна двійня, фетоплацентарна недостатність, затримка росту плода.

Ключевые слова: многоплодная беременность, монохориальная, бихориальная двойня, фетоплацентарная дисфункция, задержка роста плода.

Key words: multiple pregnancy, monochorionic twins, bichorionic twins, fetoplacental insufficiency, fetal growth retardation.

ВСтуп. Охорона здоров'я матері і плода є пріоритетним напрямком сучасної медицини. Проблема невиношування вагітності займає одне з провідних місць у сучасному акушерстві, оскільки це ускладнення обумовлює високу перинатальну захворюваність і смертність $[2,3,6]$. Частота невиношування постійно збільшується і становить 15-20 \% при одноплідній вагітності. Особливо гостро ця проблема стосується багатоплідної вагітності 3 частотою невиношування до 54,3 \%, що в кілька разів перевищує показники при вагітності одним плодом. Втрачені вагітності при багатоплідності складають майже 17 \% всіх бажаних вагітностей, 75-80 \% викиднів відбуваються на ранніх термінах: 17 \% багатоплідних вагітностей переривається у 20-27 тижнів, $21 \%$ - між
28 і 31 тижнями, 17 \% пологів - між 32 і 36 тижнями. У ІІ триместрі відбувається майже 18-20 \% усіх переривань багатоплідних вагітностей, в III - 7-30\%. Серед пологів, що відбулися до 32 тижнів, 25 \% складають багатоплідні пологи [2, 3, 8].

Багатоплідна вагітність на сьогодні все більше привертає увагу вчених, оскільки пов'язана з високим ризиком розвитку перинатальної патології $[2,8]$. Найбільш часті ускладнення, що зустрічаються при багатоплідній вагітності: загроза переривання вагітності, передчасні пологи, гестоз, фетоплацентарна дисорункція, дискордантний розвиток плодів, затримка росту і антенатальна загибель одного і більше плодів вимагають тривалого лікування і значних матеріальних витрат [2, 3, 7 ]. 
Причини передчасних пологів досить численні і часто виходять за межі акушерської науки і практики, будучи медико-соціальною проблемою. У процесі дослідження виявлено безліч фракторів, які пов'язані 3 розвитком невиношування і передчасних пологів, з них генетичні складають $80 \%$, імунні - 27-44 \%, ендокринні - 30-78 \%, інсекційні - майже 50 \%, маткові - близько 11-14\%. Більшість 3 цих фракторів можна виявити ще до початку гестації, деякі - на ранніх ії̈ термінах. Оцінка ступеня ризику невиношування вагітності $€$ надзвичайно вагомою з практичної точки зору. Морфологія плаценти при невиношуванні вагітності певною мірою може відображати етіологію і патогенез цієї патології. Аналіз літературних даних дозволяє зробити висновок про те, що персистуюча вірусна і бактеріальна інфекції є значними фракторами невиношування вагітності. При з'ясуванні можливих причин і розуміючи патогенез невиношування вагітності, можна прогнозувати і успішно проводити патогенетичне лікування даного ускладнення $[1,4,10]$.

Мета дослідження - вивчення імуноморсоологічних особливостей плаценти при багатоплідній вагітності в залежності від типу плацентації і термінів розродження.

МАТЕРІАЛИ ТА МЕТОДИ. Проведено ретроспективниЙ аналіз 65 історій пологів двійнятами за 2012-2015 рр. на базі Сумського обласного клінічного перинатального центру. Здійснено морфологічне дослідження послідів цих вагітних (I група - 30 послідів жінок із передчасними пологами, II група - 35 послідів жінок, у яких пологи відбулися в терміні доношеної вагітності, контрольну групу склали 50 послідів жінок з доношеною одноплідною вагітністю). У всіх пацієнток отримано письмовий дозвіл на дослідження біоматеріалу відповідно до чинного законодавства.

Морфологію послідів вивчали за допомогою гістологічних, гістохімічних та імуноморфологічних методів. Шматочки посліду фріксували у 10 \% нейтральному формаліні, заливали в целоїдин-парафрін, виготовляли зрізи товщиною 5-6 мкм. Зрізи фрарбували гематоксилінеозином, пікрофуксином за ван-Гізоном і методом Малорі. Глікозаміноклікани ідентиорікували за методом В. В. Виноградова і Б. Б. Фукса, РНК виявляли реакцією Браше (контроль 3 кристалічною рибонуклеазою), ДНК - реакцією Фельгена - Россенбека $[10,11]$. Імуноморфологічні дослідження проводили на парафрінових зрізах непрямою реакцією Кумбса за методикою Brosman [9]. Імунні клітини диференціювали за допомогою моноклональних антитіл (МКА) до різних типів клітин ( «Chemicon», (USA). Використовували LT8 (CD8), LT4 (CD4), LT3 (CD3), LT22 (CD22), LNK16 (CD16), LD18 (CD18). Колагени типували за допомогою МКА до колагену I і IV типів (Novocastra Laboratories LTD) [11]. Колаген III виявляли в реакціях 3 MKA до колагену III типу ( «IMTEK», LTD, Росія). Ендотелін (ЕT-1) визначали реакцією з МКА до ендотеліну-1 («Novocastra Laboratories», LTD). Відносні об'єми деяких структурних компонентів плаценти визначали за допомогою мікроскопа «Olimpus» 3 використанням відповідного програмного забезпечення. Інтенсивність світіння ендотеліну визначали на мікрофрлюориметрі з ФЕУ-35 і виражали умовними одиницями, рівними струму, що протікає через вимірювальний прилад, вираженими в мікроамперметр (мкА). Статистичну обробку отриманого в ході дослідження цифрового матеріалу проводили параметричними методами з використанням комп'ютерних статистичних програм [5]. Статистичні дані цитовані з дисертаційної роботи Ірини Миколаївни Нікітіної «Затримка розвитку плода у вагітних, зайнятих у виробництві суперфоссрату (прогнозування, профрілактика та лікування)», захищеної у 2010 році. В дисертаційній роботі дані оброблялися 3 застосуванням варіаційно-статистичного методу аналізу отриманих результатів за допомогою персонального комп'ютера IBM PC Intel Ce1eron ${ }^{\mathrm{T}} 556 \mathrm{MHz}$ та прикладної програми роботи з електронними таблицями Microsoft ${ }^{\circledR}$ Excel 97 в середовищі Windows Millenium. Статистичну обробку матеріалу проводили методами варіаційної та парної статистики, а також застосовували метод відмінності 3 використанням t-критерію Стьюдента. Отримані результати вважали вірогідними, якщо коефіцієнт достовірності р, який знаходили по таблиці Стьюдента, був меншим 0,05.

РЕЗУЛЬТАТИ ДОСЛІДЖЕННЯ ТА ЇХ ОБГОВОРЕННЯ. 3 метою встановлення морфологічних особливостей плаценти при невиношуванні у жінок з багатоплідною вагітністю проведено порівняння результатів гістологічного дослідження плацент при передчасних пологах з 35 результатами II групи в разі термінових пологів, що ускладнювалося виникненням загрози переривання в II і III триместрах. Макроскопічно у вагітних I групи переважав монохоріальний тип плацентації - 21 (70\%). У 6 (20\%) випадках в I групі відзначалися циркулярні інсраркти, клиноподібної фрорми білі інфраркти в діаметрі від 1 до 3 см -у 23,3 \% послідів I групи і 8,6 \% випадків - у II групі. Плодо-

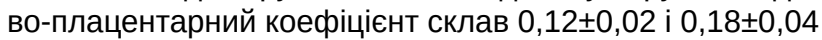
відповідно. У всіх випадках передчасних пологів спостерігалися гістологічні ознаки хронічної фретоплацентарної недостатності, причинами розвитку якої були запальні зміни і порушення кровотоку в самій плаценті, порушення розвитку судин ворсин або здавлення їх фріброзною тканиною. Фетоплацентарна недостатність у першій групі була обумовлена як відставанням дозрівання ворсин (збільшення в обсязі термінальних і проміжних ворсин, поява клітин Лангерганса, відсутність синцитіокапілярних мембран), так і хаотичним склерозуванням (поширення дрібних хаотично розташованих склерозованих ворсин зі зниженою кількістю судин, масивним розростанням колагенових волокон). Варіант дисоційованого розвитку плаценти, а саме значна кількість незрілих ворсин з відкладенням фрібриноїду в синцитії і судинах з порушенням дозрівання зустрічався при передчасних пологах, проте, в основному, переважав у II групі при термінових пологах. У всіх випадках при термінових пологах спостерігалася компенсаторна гіперплазія нових ворсин, в основному, в периферичної частини плаценти за типом нової хвилі інвазії хоріона, що не відзначалося ні в одному випадку при передчасних пологах. Відносний об'єм фрібриноїдних перетворень у ворсинчастому хоріоні незначний (табл. 1).

При мікроскопічному дослідженні в плацентах у всіх групах чітко розрізняються всі три зони: базальна мембрана, ворсинчастий хоріон, хоріональна пластинка [10, 11]. Плацента в контрольній групі гладка, з блискучою сірувато-білою поверхнею, базальна пластинка у вигляді дистрофічно змінених децидуальних клітин, незначних осередків фрібриноїдної субстанції, в складі якої і навколо децидуальних клітин відзначається світіння колагену III типу, менше виражена інтенсивність світіння колагену I типу (рис. 1). 


\section{Акушерство та гінекологія}

Таблиця 1. Відносні об'єми основних структурних компонентів плаценти в групах порівняння

\begin{tabular}{|l|c|c|c|}
\hline \multicolumn{1}{|c|}{ Структурні компоненти плаценти } & Контроль & I група & II група \\
\hline Міжворсинчастий простір & $23,7 \pm 0,8$ & $19,5 \pm 2,0^{*}$ & $18,7 \pm 2,0$ \\
\hline Материнський фібриноїд & $1,8 \pm 0,5$ & $3,2 \pm 0,8^{*}$ & $3,7 \pm 0,7$ \\
\hline Строма ворсин & $29,3 \pm 2,0$ & $31,2 \pm 2,1^{*}$ & $33,6 \pm 3,2$ \\
\hline Фібриноїд плодовий & $1,6 \pm 0,3$ & $2,3 \pm 2,6^{*}$ & $2,9 \pm 0,6$ \\
\hline Судини ворсин & $5,8 \pm 0,5$ & $5,4 \pm 0,4^{*}$ & $5,5 \pm 0,3$ \\
\hline Ділянки ворсин, склеєні фрібрином & $2,1 \pm 0,7$ & $3,7 \pm 0,6^{*}$ & $4,7 \pm 0,8$ \\
\hline Інфраркти і крововиливи & $0,3 \pm 0,02$ & $1,5 \pm 0,6^{*}$ & $2,1 \pm 0,9$ \\
\hline Кальцинати & $0,5 \pm 0,03$ & $1,2 \pm 0,07^{*}$ & $1,9 \pm 0,09$ \\
\hline Запальна інфільтрація & $0,4 \pm 0,02$ & $1,8 \pm 0,09^{\star}$ & $2,8 \pm 0,7$ \\
\hline \hline
\end{tabular}

Примітка. * - p<0,5 порівняно 3 контролем.

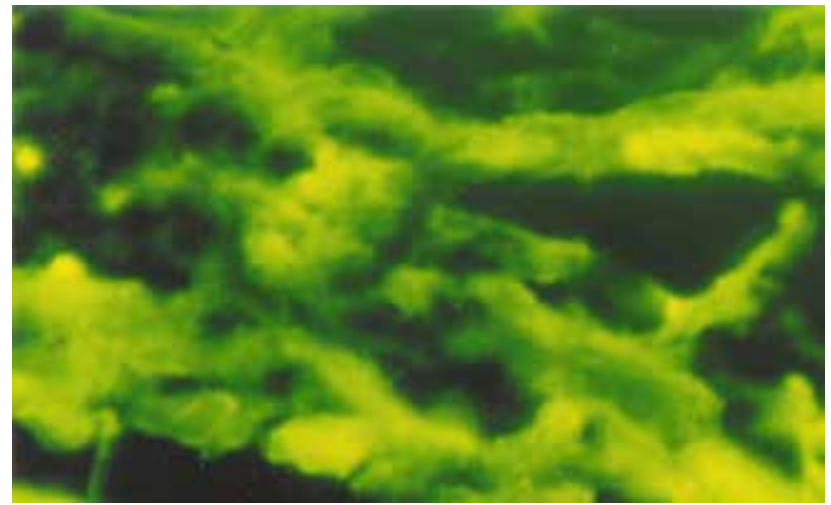

Рис. 1. Яскраве свічення колагену III типу в децидуальній оболонці плаценти в контрольній групі. Непрямий метод Кумбса з МКА до колагену III типу, ×900.

У першій групі при мікроскопічному дослідженні привертають увагу помірно виражений набряк усіх складових компонентів посліду. Плацента набрякла, в результаті чого кордони між котиледонами згладжені. У товщі котиледонів частіше, ніж у контрольній групі, виявляються інфраркти та петрифрікати. Компенсаторно-пристосувальні процеси, що зумовлені глибокими розладами гемодинаміки, явищами деструкції і дистрофії, не завжди виражені. У фрібриноїдній субстанції спостерігається слабке, місцями помірної інтенсивності, світіння колагену І типу. У клітинному інфрільтраті визначаються макрофраги і нейтрофріли (рис. 2).

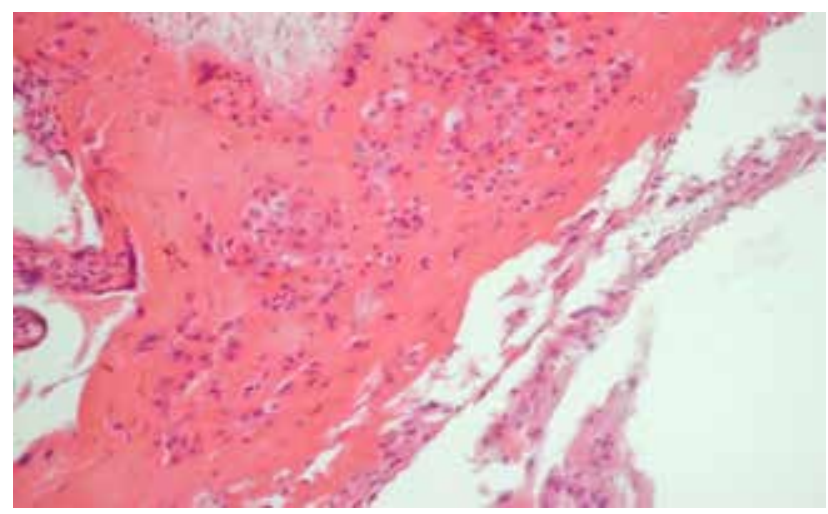

Рис. 2. Виражена лімсоо-плазмоцитарна і нейтрофрільна інфільтрація в децидуальній оболонці плаценти в I групі. Забарвлення гематоксиліном і еозином, ×200.
У порівнянні з контрольною групою, в капілярах і артеріолах ворсин I і II порядку відзначався ендотеліоз - гіперплазія ендотеліоцитів, місцями часткова або повна облітерація судин. При імуноморфологічному дослідженні виявляється нерівномірне світіння колагену IV типу у складі базальних мембран синцитію і судин, і осередкове, помірної інтенсивності, світіння колагену III типу в синцитіоендотеліальному просторі, що свідчить про зміни склеротичного напрямку. У порівнянні з контролем, відносний об'єм фрібриноїдної субстанції у ворсинчастому хоріоні дещо збільшений, також мають місце посилені дистрофічні процеси на тлі помірно вираженого набряку усіх відділів посліду. Виявляються вогнища колікваційного некрозу, порушення дозрівання ворсинчастого хоріона в комбінації з імунопатологічними реакціями у вигляді вираженої лімсоо-плазмоцитарної і макрофрагальної реакцій, відкладення імунних комплексів на базальних мембранах судин і епітелію. Ультраструктурні дослідження плаценти жінок II групи показали, що структурна організація ії елементів не зазнала значних змін. На тлі вираженого набряку усіх відділів посліду, гідропічної дистрофрії і колікваційного некрозу децидуальної оболонки відзначається порушення дозрівання ворсинчастого хоріона, посилення інволютивних процесів, а також розвиток імунопатологічних реакцій у вигляді свічення фрібриноїду, вираженої лімфо--плазмоцитарної і макрофрагальної реакцій, відкладення імунних комплексів на базальних мембранах судин і епітелію (рис. 3).

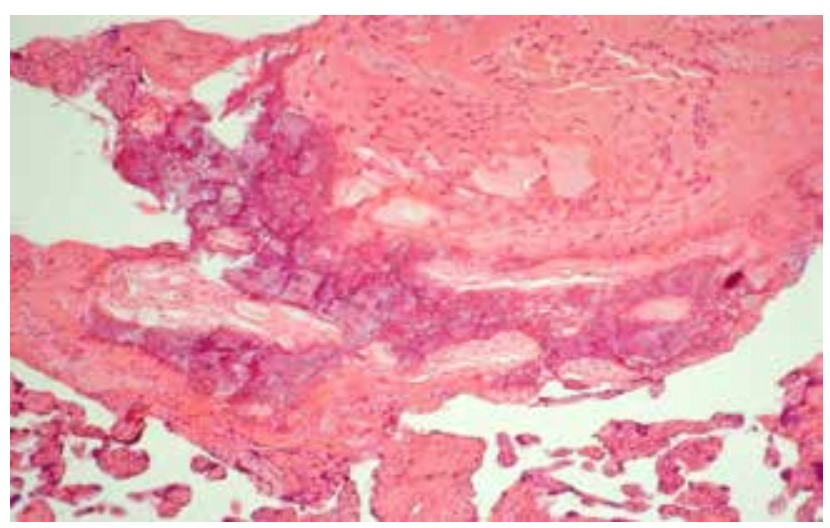

Рис. 3. Колікваційний некроз у децидуальній оболонці плаценти в II групі. Забарвлення гематоксиліном і еозином, $\times 200$. 
При вивченні стовбурових ворсин встановлено, що, у порівнянні з нормою, вони зменшені в розмірах, вкорочені і стоншені. Спостерігається розростання фріброзної тканини, часто одночасно в декількох поруч розташованих проміжних ворсин. $€$ осередкові і тотальні ділянки гомогенізації строми стовбурових і проміжних ворсин, лізис сполучнотканинних елементів. Термінальні ворсини мають невеликі розміри, виглядають недорозвиненими і розташовані щільно один до одного, що призводить до звуження міжворсинчастого простору і ускладнює кровообіг в ньому, відзначається значне нашарування фрібриноїду на поверхні ворсин. У стовбурових і проміжних ворсин спостерігаються виражені патологічні зміни судин мікроциркуляторного русла. Виявлено велику кількість вогнищ плазмо- і геморагій у строму ворсин. Вени і венули паретично розширені, їх стінка значно стоншена. Стінки судин просякнуті гомогенною масою й інорільтровані лімфоїдними елементами. У II групі відзначається набряк плаценти, кордони між котиледонами згладжені. Звертає на себе увагу збільшення відносного об'єму фрібриноїдної субстанції в децидуальній оболонці, де спостерігається виражена лімсро-плазмоцитарна і макрофрагальна реакції.

Базальна мембрана амніона нерівномірно потовщена нерівномірно ШИК-позитивна, ділянки яскраво-малинового кольору чергувалися з дуже блідими зонами. При імуногістохімічному дослідженні в ії̈ складі визначався колаген IV типу у вигляді лінійного 3 нерівномірною інтенсивністю світіння.

У цих зонах виявляється фріксація імунних комплексів, що складаються з IgM, IgG, C-3 фрракції комплементу. У цитоплазмі епітеліоцитів виявлялася нерівномірної інтенсивності ШИК-реакція, а також яскраво або помірно-позитивна реакція Браше на РНК. У цих клітинах ядра помірно базофільні, хроматин переважно у вигляді еухроматину, внаслідок чого реакція Фельгена - Россенбека на ДНК (контроль гідроліз з НС1) слабо-позитивна.

У сплощеному кубічному епітелії переважав гетерохроматин, при цьому виявлялася яскраво-позитивна реакція Фельгена - Россенбека на ДНК. Наслідком високого навантаження метаболічних процесів в епітеліоцитах була, очевидно, їх виражена проліферація з утворенням великої кількості амніотичних ворсинок (рис. 4).

Слід підкреслити особливість плацент при передчасних пологах - в 100 \% випадків виявлені ознаки запалення, яке характеризувалося вогнищевим серозним, серозно-гнійним парієтальним децидуїтом (44,4 \%), вогнищевим серозно-гнійним мембранітом (24,4 \%), поєднанням мембраніту з децидуїтом і серозно-гнійним вілузитом (22,2 \%), фунікулітом і васкулітом (9,0\%). Ознаки запалення в плаценті такого ж характеру визначалися і при термінових пологах, проте частота їх становила лише $22 \%$. Таким чином, морфологічними особливостями плаценти при передчасних пологах двійнею є: інфрекційне ураження і хронічна фретоплацентарна недостатність 3 порушенням кровотоку в самій плаценті і нездатність

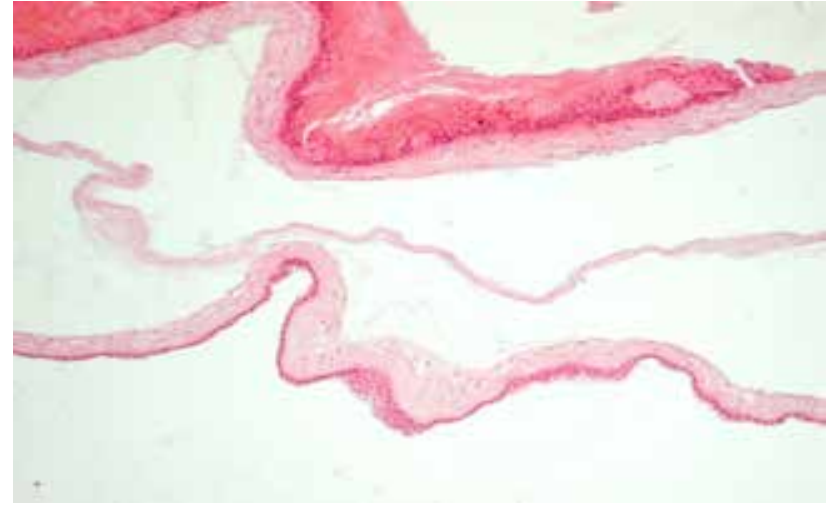

Рис. 4. Амніотичні ворсини і явища фрібриноїдної трансфрормації амніона в II групі. Забарвлення гематоксиліном і еозином, $\times 100$.

плаценти до компенсаторної гіперпродукції нових ворсин за типом «свіжої» хвилі інвазії хоріона.

Висновок. Таким чином, за результатами проведеного дослідження можна зробити такі висновки:

1. Вивчаючи імуноморфологічні особливості плаценти при багатоплідній вагітності, слід зазначити, що ступінь фретоплацентарної дисфрункції залежить від кровопостачання плаценти і характеру запальних змін, що проявляється у різній морфологічній картині плацентарних порушень.

2. Морфологічними проявами дезорганізації плаценти при передчасних пологах, патогенетично обумовлених інфрікуванням матері і плода, є вогнищева затримка дозрівання ворсин, редукція судинного русла, щільність міжворсинчастих просторів, поліморфно-клітинна запальна інсрільтрація, ворсинки зі стоншеним хоріональним епітелієм, а також стаз формених елементів крові в судинах плаценти, склерозування і фрібриноїд ворсинок.

3. Морфологічними ознаками фетоплацентарної дисфрункції при неінфекційних фракторах як причині невиношування вагітності є: ранні зміни в судинах децидуальної оболонки у вигляді спазму, облітерації просвіту спіральних артерій, зменшення об'єму судинного русла, об'єму хоріонального епітелію і периферичного трофобласта, збільшення відкладань материнського і плодового фрібриноїду.

4. Дослідження плаценти дозволяє сорормулювати чітку концепцію, яка дозволить на підставі виявлених імуноморфологічних особливостей проводити патогенетично обґрунтовану терапію ускладнень як при багатоплідній, так і при одноплідній вагітності.

ПЕРСПЕКТИВИ ПОДАЛЬШИХ ДОСЛІДЖЕНЬ ОбУмовлені недостатньо повним вивченням імуноморфологічних процесів, що відбуваються у фретоплацентарному комплексі, та їх ролі у розвитку фетоплацентарної дисфрункції, що, у свою чергу, не дозволяє повністю розкрити механізм патогенезу формування ускладнень, що виникають у ході гестаційного процесу на цьому тлі. 


\section{СПИСОК ЛІТЕРАТУРИ}

1. Алещенко И. Б. Морфологічні особливості плаценти і гормональне співвідношення при гіпертиреозі И. Б. Алещенко, А. П. Милованов // Архів патології. - 2001. - № 3. - С. 26-30.

2. Баранов І. І. Перинатальні наслідки при багатоплідних пологах / І. І. Баранов, 3. 3. Токова, А. А. Тадевосян // Акушерство і гінекологія. - 2012. - № 1. - С. 98-102.

3. Гинсбург Б. Г. Цитогенетические аспекты невынашивания беременности в системе медико-генетического консультирования / Б. Г. Гинсбург // Проблемы репродукции. -2000 . - № 1. - С. 57-59.

4. Говорка Э. Плацента человека / Э. Говорка. - Варшава : Польское гос. мед. из-во, 2000. - С. 470.

5. Лапач С. Н. Статистичні методи в медико-біологічних дослідженнях з використанням Exel / С. Н. Лапач, А. В. Чубенко, П. Н. Бабич. - К. : Моріон, 2000. - С. 320.

6. Сидельникова В. М. Инфрекция как ведущий фрактор невынашивания беременности / В. М. Сидельникова //
Материалы II Российского форума «Мать и дитя»: сб. научн. тр. - М., 2000. - С. 134-135.

7. Цинзерлинг В. А. Перинатальные инсрекции (вопросы патогенеза, морфологической диагностики и клинико-морфологических сопоставлений). Практическое руководство / В. А. Цинзерлинг, В. Ф. Мельникова. - СПб. : Элби СПб, 2002. - C. 352.

8. Blickstein I. Multiple Pregnancy / I. Blickstein, L. G. Keith. - Epidemiology, Gestation \& Perinatal outcome. - Informa UK Ltd: 2005. - P. 946.

9. Brosman M. Imunofluorescencne vysetrovanie formal-parafinovogo materialu / M. Brosman // Cs Patol. - 1974. Vol. 15 (40). - P. 215-220.

10. Castellucci M. The Hofbauer cells of the human placenta: Morphological and immunological aspects / M. Castellucci, D. Zacoheo // Prog. olin. biol. Res. - 1999. - Vol. 296. - P. 443-451.

11. Kaunfmann P. The fibrinoids of the human placenta: origin, composition and functional relevance / P. Kaunfmann, B. Huppertz, H. G. Frank // Anat. Anz. - 1996. - Vol. 178. - P. 485-501.

Отримано 10.08.16 